\title{
Single and binary effects of atrazine, copper and chromium on duckweed
}

\author{
Ảnh hưởng riêng lẻ và kết hợp của atrazine với đồng và crom lên bèo tấm \\ NGUYEN, Vu; NGUYEN, Thi Thuy Trang; Vo, Thi My Chi; DAO, Thanh Son* \\ Hochiminh City University of Technology, 268 Ly Thuong Kiet St., Dist. 10, Hochiminh City, Vietnam
}

\begin{abstract}
Recently, the agricultural, industrial and mining activities have led to increase in contaminant emission. Trace metals or herbicides are among the pollutants to be concerned in the world. In this study we evaluated the effects of the herbicide atrazine (at the concentrations of 5,50 and $\left.500 \mathrm{\mu g} \mathrm{L}^{-1}\right)$ and its combination with copper $\left(\mathrm{Cu}^{2}, 50 \mu \mathrm{g} \mathrm{L}^{-1}\right)$ and chromium $\left(\mathrm{Cr}, 50 \mu \mathrm{g} \mathrm{L}^{-1}\right)$ on duckweed over the period of 10 days in the laboratory conditions. We found that 50 and $500 \mu \mathrm{g}$ atrazine $\mathrm{L}^{-1}$ severely impacted on the growth or even caused the death of the plants, whereas there was no statistically significant difference in the duckweed growth rate between the $5 \mu \mathrm{g}$ atrazine $\mathrm{L}^{-1}$ exposure and control. In the combined treatments (50 $\mathrm{\mu g}$ atrazine $\mathrm{L}^{-1}$ with $\mathrm{Cu}$; with $\mathrm{Cr}$ or with both $\mathrm{Cu}$ and $\mathrm{Cr}$ ), the plant growth rate of atrazine with either $\mathrm{Cu}$ or $\mathrm{Cr}$ was strongly reduced. However, the mixture of atrazine with $\mathrm{Cu}$ and $\mathrm{Cr}$ did not significantly decrease the development and growth rate of duckweed. Besides, atrazine and investigated heavy metals resulted in turning white of duckweek leaves that evidence of the chlorophyll degradation. Our results showed the negative influences of the herbicide atrazine and metals on development and morphology of duckweed.
\end{abstract}

Gần đây, những hoạt động nông nghiệp, công nghiệp và khai khoáng đã và đang dẫn đến sự gia tăng phát thải các chất gây ô nhiễm. Kim loại nặng hoặc thuốc diệt cỏ là những chất gây ô nhiễm đang được quan tâm trên thế giới. Trong nghiên cứu này, chúng tôi đánh giá ảnh hưởng của thuốc diệt cỏ atrazine (nồng độ 5, 50 và $500 \mu \mathrm{gg} L^{-1}$ ) và sự kết hợp của chất này với đồng $\left(C u, 50 \mu g L^{-1}\right)$ và crom $\left(C r, 50 \mu g L^{-1}\right)$ lên bèo tấm trong thời gian 10 ngày trong điều kiện phòng thí nghiệm. Chúng tôi nhận thấy atrazine tại nồng độ 50 và $500 \mu \mathrm{g} \mathrm{L}^{-1}$ đã gây nên những ảnh hưởng nghiêm trọng lên sự phát triển hay thậm chí làm cho bèo tấm bị chết, trong khi đó, không ghi nhận được bất kì sự khác biệt có ý nghĩa thống kê về tốc độ tăng trưởng của bèo tấm giữa lô thí nghiệm phơi nhiễm $5 \mu \mathrm{g}$ atrazine L ${ }^{-1}$ và lô đối chứng. Trong những lô phơi nhiễm kết hợp (50 $\mu$ g atrazine $\mathrm{L}^{-1}$ với $\mathrm{Cu}$, với $\mathrm{Cr}$ hoặc với đồng thời $\mathrm{Cu}$ và $\mathrm{Cr}$ ), tốc độ tăng trưởng của bèo tấm khi phơi nhiễm với atrazine và Cu hoặc $\mathrm{Cr}$ b! giảm mạnh, tuy nhiên, việc phơi nhiễm đồng thời atrazine với Cu và Cr đã không làm giảm đáng kể sự phát triển và tốc độ tăng trưởng của bèo tấm. Bên cạnh đó, atrazine và kim loại nặng đã làm cho màu của lá bèo tấm chuyển sang màu trắng, điều này chứng tỏ có sự suy giảm chlorophyll. Kết quả nghiên cứu này đã cho thấy những ảnh hưởng tiêu cực của thuốc diệt cỏ atrazine và kim loại lên sự phát triển và hình thái của bèo tấm.

Keywords: Combined effects, growth rate, Lemna minor, herbicide, trace metals

\section{Introduction}

Due to the high anthropogenic pressure, the presence of trace metals with high concentration is one of the most important environmental issues in the world. At low concentrations, the heavy metals copper (Cu) and chromium (Cr) are among the essential elements for plants' growth (WHO, 1996). Under certain environmental conditions, these contaminants can accumulate up to a concentration which is toxic and cause damages to plants (Naggar et al., 2018). The exposure to Cu results in phytotoxic impacts, particularly chlorosis, inhibition of root growth and damage to the permeability of plasma's membrane (Sheldon and Menzies, 2005; Ali et al., 2002; Ouzounidou, 1994a; Ouzounidou, 1994b). Similarly, effects of elevated Cr concentration on plants (Echinochloa colona, Phaseolus vulgaris,
Medicago sativa) have been also reported through decrease in seed germination and root growth (Rout et al., 2000; Parr and Taylor, 1982; Paralta et al., 2001). Moreover, $\mathrm{Cr}$ stress causes detrimental effects on the photosynthesis in terms of $\mathrm{CO}_{2}$ fixation, electron transport, photophosphorylation and enzyme activities from in vitro experiments with bean, Phaseolus vulgaris (e.g. reviewed by Clijsters and van Assche, 1985).

In order to protect the crops, insecticides and herbicides are commonly used in agricultural fields (Chen et al., 2015). Therefore, along with trace metals, pesticides are also widely present in the environment (Wang et al., 2012). According to previous studies, almost all pesticides pose a potential risk to both humans (Forget, 1993; Igbedioh, 1991) and non-target wildlife such as amphibians 
(McMahon et al., 2011; Rohr et al., 2003; Rohr and McCoy, 2010), arthropods (Desneux et al., 2007; Stark and Banks, 2003) and fish species (Rohr and McCoy, 2010). Among the most common pollutants, atrazine (2-chloro-4-ethylamino6-isopropylamino-1,3,5-triazine) belongs to the s-triazine herbicides that has been widely used on many crops (Wang et al., 2012). This xenobiotic is known to act as an endocrine disruptor in fish and amphibians (Dalton, 2002; Hecker et al., 2005). Additionally, several studies demonstrated that the growth rate of duckweeds decreased significantly after being exposed to this chemical at the concentration of $170 \mathrm{\mu gL}^{-1}$ (Hughes et al., 1988; Phewnil et al., 2012).

Although research studies are focused on the toxicity and the fate of $\mathrm{Cu}, \mathrm{Cr}$ or atrazine in the environment, only a few studies aimed at assessing the combined effects of atrazine, Cu and $\mathrm{Cr}$. On the other hand, the duckweed toxicity tests received much attention lately as this plant has many features that make it suitable for culturing or testing (Wang, 1990). Hence, in this study, we examined the single and combined effects of atrazine, $\mathrm{Cu}$ and $\mathrm{Cr}$ on the development of the duckweed Lemna minor L. in order to provide useful information for designing proper strategies toward the protection of environment and human health.

\section{Materials and methods}

\subsection{Materials}

Both trace metals ( $\mathrm{Cu}$ and $\mathrm{Cr}$ ) in stock solution of 1,000 mg $\mathrm{L}^{-1}$ and atrazine for toxicity tests were purchased from the manufacturer Merck (Germany). Atrazine was dissolved in $\mathrm{MeOH}$ at the concentration of $1 \mathrm{mg} \mathrm{mL}^{-1}$ and this stock solution was kept at $-4^{\circ} \mathrm{C}$ prior to the experiment. The duckweed, Lemna minor L. was collected from a small pond in the District 12 of Hochiminh City and it was cultivated in Z8 medium (Kotai, 1972). During culturing and exposure, the experimental conditions included: air temperature of $27 \pm 2$ ${ }^{\circ} \mathrm{C}$, a photoperiod of $12 \mathrm{~h}$ light / 12h dark cycle, and a light intensity of around 2,500 Lux.

\subsection{Experimental setup}

Toxicity tests of $\mathrm{Cu}, \mathrm{Cr}$ and atrazine were conducted according to the introduction of APHA (2012) and Khellaf and Zerdaoui (2009) with some minor adjustments. Duckweeds were exposed to atrazine at four distinct concentrations: 0 (control), 5, 50 and $500 \mu \mathrm{gL}^{-1}$. The plants were also treated with a mixture of atrazine and $\mathrm{Cu}$, atrazine and $\mathrm{Cr}$, or atrazine and both $\mathrm{Cu}$ and $\mathrm{Cr}$ (at the concentration of 50 $\mu \mathrm{LL}^{-1}$ for each experimental chemical). The concentrations of atrazine used in this study were smaller than $691 \mathrm{\mu gL}^{-1}$ as reported elsewhere (Lockert et al., 2006). The Cu and Cr concentrations in our study were within the allowable metal concentrations (200 $\mu \mathrm{g} \mathrm{Cu} \mathrm{L}{ }^{-1}$ and $\left.100 \mu \mathrm{g} \mathrm{Cr} \mathrm{L}{ }^{-1}\right)$ in the National Technical Regulation on Surface Water Quality of Vietnam (QCVN 08-MT:2015/BTNMT). In each treatment, three duckweed plants, each with two leaves, were cultured over a period of 10 days in a beaker containing 200 $\mathrm{mL}$ of $\mathrm{Z8}$ medium. Five replicates were prepared for each treatment. During the experimental period, the number of plants in each treatment was recorded daily.

\subsection{Data treatment}

The following equation was used to calculate the growth rate (R) of duckweeds (eq. 1):

$R=\frac{\ln X_{2}-\ln X_{1}}{t_{2}-t_{1}}$

where $X_{1}$ and $X_{2}$ are the duckweed densities at time $t_{1}$ and $t_{2}$, respectively (Lobban et al., 1988). The significant difference on the number of plants and the growth rate between control, single and combined exposures was evaluated using the Kruskal-Wallis test (SigmaPlot Version 12).

\section{Results and discussion}

The number of plants exposed to atrazine at the lowest concentration $\left(5 \mu \mathrm{gL}^{-1}\right)$ was statistically higher than that in the control starting from day 4 to day 9 of the incubation (13.4 to 101.0 plants per beaker in atrazine exposure; 9.6 to 61.8 plants per beaker in control; $p=0.030-0.001$; Fig. 1). The reason could be that at low doses, atrazine stimulates the plant growth rate through beneficial effects on nitrogen metabolism (Edivaldo et al., 2010). However, during almost the entire experimental period, there was no statistical difference in the number of plants between those exposed to atrazine at the concentration of $50 \mathrm{\mu gL}^{-1}$ and control. Nevertheless, after two days of incubation, the total number of plants observed in atrazine-exposed treatment at the highest concentration (500 $\mathrm{\mu g}^{-1}$ ) was statistically lower than that in control (Fig. 1). These results are similar to previous study of Hughes et al. (1988), in which the authors determined that the 50\% inhibition concentrations of herbicide atrazine for Lemna gibba was $170 \mu \mathrm{gL}^{-1}$.

Numerous studies confirmed that atrazine affected plants by interfering the electron transfer of the Photosystem II (PSII) of the photosynthesis process (Giardi et al., 2001; Bell and Duke, 2005; Graymore et al., 2001). As a result, during the period of 10 experimental days, there was no statistically significant difference in the growth rate between the atrazine exposure at the lowest concentration $\left(5 \mu \mathrm{gL}^{-1}\right)$ and the control. However, the plants exposed to atrazine at the concentration of $50 \mu \mathrm{gL}^{-1}$ had the growth rate statistically lower $(p=0.041)$ than that in the control, even the value of the growth rate in atrazine treatment at the highest concentration $\left(500 \mu \mathrm{LL}^{-1}\right)$ being negative $(p=0.008)$ (Fig. 2). Similarly, Phewnil et al. (2012) also showed that the growth rate of Lemna perpusilla significantly decreased when the plant was exposed to atrazine in concentrations from 250 to $32,000 \mu g L^{-1}$. 


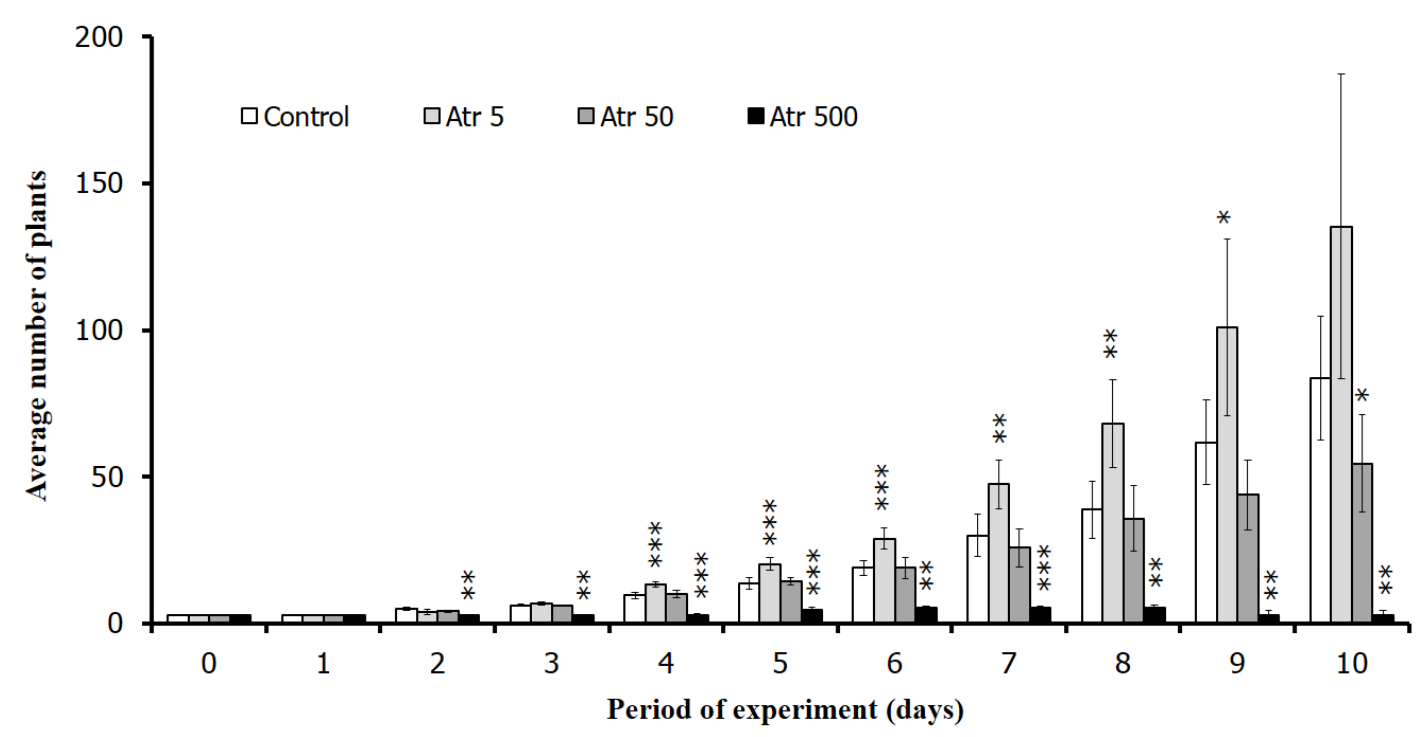

Figure 1. The development of duckweed exposed to atrazine at three distinct concentrations. Atr 5, Atr 50, Atr 500: plants exposed to atrazine at the concentration of 5,50,500 $\mathrm{gL}^{-1}$, respectively. The asterisk indicates the significant difference between control and exposures $(* 0.01 \leq \mathrm{p} \leq 0.05 ; * * 0.001 \leq \mathrm{p} \leq 0.01 ; * \star * \mathrm{p} \leq 0.001$ by Kruskal-Wallis test)

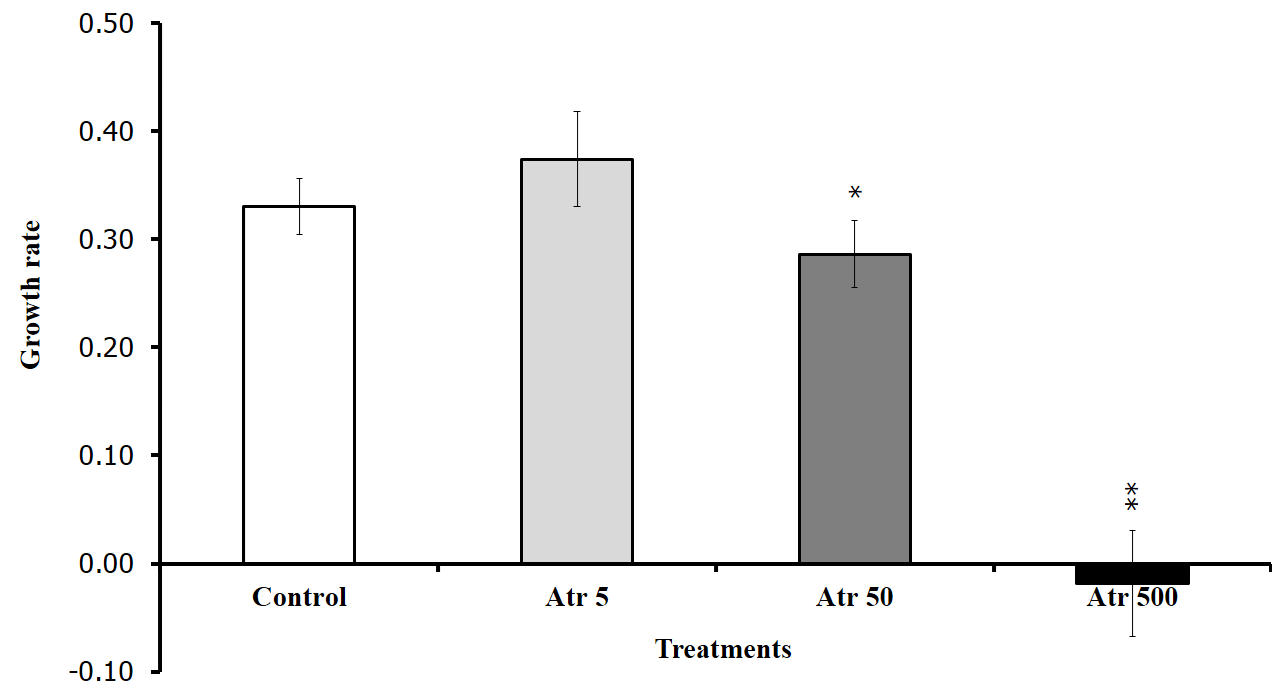

Figure 2. The growth rate of duckweed exposed to atrazine at three distinct concentrations. Atr 5, Atr 50, Atr 500: plants exposed to atrazine at the concentration of $5,50,500 \mathrm{\mu gL}^{-1}$, respectively. The asterisk indicates the significant difference between control and exposures $(* 0.01 \leq p \leq 0.05 ; * * 0.001 \leq p \leq 0.01 ; * * * p \leq 0.001$ by Kruskal-Wallis test)

In the chemical mixture treatments, there were statistical differences ( $p<0.05$; Table 1 ) noted in the number of plants when comparing the control with exposures where the plants were treated with a mixture of atrazine and $\mathrm{Cu}$, atrazine and $\mathrm{Cr}$ or atrazine and both $\mathrm{Cu}$ and $\mathrm{Cr}$. Specifically, the simultaneous exposure to atrazine and Cu or atrazine and $\mathrm{Cr}$ had the total number of plants statistically lower than the control in almost all the experimental days (on day $2,4,6,7,8,9$ and 10 for atrazine and Cu exposure; on day 2, 4, 5, 6, 7, 8, 9 and 10 for atrazine and Cr exposure) (Table 1). Compared with atrazine exposure at the concentration of $50 \mu \mathrm{gL}^{-1}$ (Fig. 1), the effect of this herbicide along with $\mathrm{Cu}$ or $\mathrm{Cr}$ at the concentration of $50 \mathrm{\mu gL}^{-1}$ for each experimental chemical on the total number of plants seemed to be more serious. In previous studies, the combination of atrazine and metals such as Cu or Cd exhibited a slight degree of synergism effects on living organisms (Yang et al.,
2015; Roberts et al., 1990). In contrast, the growth rate of duckweed exposed to the mixture of atrazine, $\mathrm{Cu}$ and $\mathrm{Cr}$ treatment was not statistically different to the control, excepting the experimental day 4 , when the total number of plants was statistically higher than that in the control (Table 1). This phenomenon could be explained by the fact that atrazine contains five electron-donor atoms which can potentially combine with other chemicals such as trace metals (Cu or $\mathrm{Cr}$ ) to form atrazine-metal complexes resulting in the reduction of the toxicity characteristics of atrazine (Meng and Carper 2000). Consequently, the growth rate of plants exposed to the mixture of atrazine and $\mathrm{Cu}$ or $\mathrm{Cr}$ at the concentration of $50 \mu \mathrm{gL}^{-1}$ for each chemical was statistically lower than that in the control $(p=0.001)$. Surprisingly, when the plants were exposed simultaneously to atrazine, $\mathrm{Cu}$ and $\mathrm{Cr}$, the growth rate in this treatment was not statistically different from that in the control (Fig. 4). 
Table 1. The development of duckweed exposed to the mixture of atrazine and trace metals. Atr $+\mathrm{Cu}, \mathrm{Atr}+\mathrm{Cr}, \mathrm{Atr}+\mathrm{Cu}+\mathrm{Cr}$ : plants exposed simultaneously to atrazine and $\mathrm{Cu}$, atrazine and $\mathrm{Cr}$, atrazine and $\mathrm{Cu}$ and $\mathrm{Cr}$, respectively, at the concentration of $50 \mathrm{\mu gL}^{-1}$ for each experimental chemical. The asterisk indicates the significant difference between control and exposures (* $p<0.05 ; * * p<0.01 ; * * * p \leq 0.001$ by Kruskal-Wallis test).

\begin{tabular}{|c|c|c|c|c|}
\hline \multirow[b]{2}{*}{ Days of exposure } & \multicolumn{4}{|c|}{ Average number of plants per beaker } \\
\hline & Control & Atr $+\mathrm{Cu}$ & $\mathrm{Atr}+\mathrm{Cr}$ & $\mathrm{Atr}+\mathrm{Cu}+\mathrm{Cr}$ \\
\hline 0 & $3.0 \pm 0.0$ & $3.0 \pm 0.0$ & $3.0 \pm 0.0$ & $3.0 \pm 0.0$ \\
\hline 1 & $3.0 \pm 0.0$ & $3.0 \pm 0.0$ & $3.0 \pm 0.0$ & $4.0 \pm 1.4$ \\
\hline 2 & $5.0 \pm 0.7$ & $3.2 \pm 0.4^{\star * *}$ & $3.4 \pm 0.5^{\star \star}$ & $5.0 \pm 1.2$ \\
\hline 3 & $6.2 \pm 0.4$ & $6.0 \pm 0.0$ & $6.0 \pm 0.0$ & $6.4 \pm 0.9$ \\
\hline 4 & $9,6 \pm 1.1$ & $6.6 \pm 0.5^{* \star *}$ & $6.4 \pm 0.5^{\star \star \star}$ & $12.4 \pm 1.1$ ** \\
\hline 5 & $13.6 \pm 1.9$ & $11.4 \pm 1.5$ & $10.4 \pm 1.7^{*}$ & $17.6 \pm 4.7$ \\
\hline 6 & $19.0 \pm 2.5$ & $14.8 \pm 1.1 * *$ & $13.6 \pm 1.1 * \star$ & $23.2 \pm 4.4$ \\
\hline 7 & $30.0 \pm 7.2$ & $19.0 \pm 2.1 *$ & $16.4 \pm 2.9 * \star$ & $33.2 \pm 7.2$ \\
\hline 8 & $38.8 \pm 9.8$ & $27.6 \pm 3.4^{*}$ & $24.8 \pm 3.6^{*}$ & $49.2 \pm 10.0$ \\
\hline 9 & $61.8 \pm 14.5$ & $35.0 \pm 4.6 * \star$ & $32.4 \pm 3.9 * *$ & $58.0 \pm 10.9$ \\
\hline 10 & $83.8 \pm 21.1$ & $43.4 \pm 4.0^{\star \star}$ & $39.8 \pm 5.0 * \star$ & $68.4 \pm 12.9$ \\
\hline
\end{tabular}

During the experiments, it was noticed that the color of the duckweed leaves changes in some chemical treatments. The Cu treatment caused the pale in leaves of duckweed (Fig. 4B) compared to the control (Fig. 4A). More seriously, the mixture of $\mathrm{Cu}$ and atrazine resulted in the apparition of white parts or dots on the plant leaves (Fig. 4C). Ouzounidou (1994b) also observed the pigment reduction in plant leaves upon exposure to $\mathrm{Cu}$ at the concentration of around $250 \mu \mathrm{gL}^{-1}$. Similarly, atrazine could also negatively interfere the electron transfer of photosynthesis process consequently pigment and chloroplast impairment in plants (Graymore et al., 2001; Bell et al., 2005). These mechanisms helped to explain the pigment reduction in leaves of duckweed exposed to Cu and mixture of Cu and atrazine in our study. Therefore, in agricultural activities (e.g. in Mekong Delta in Vietnam) the high potential risk to plants and crops due to herbicides application and metal emission needs to be clarified by in situ investigations.

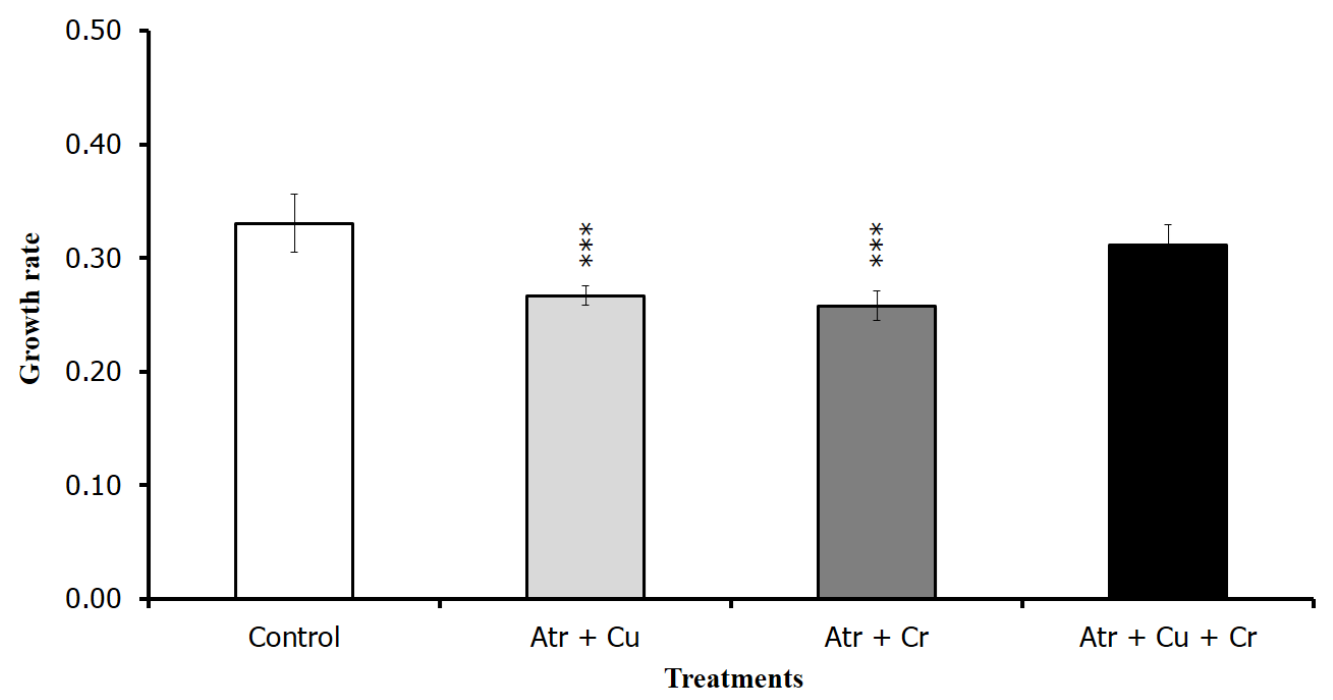

Figure 3. The growth rate of duckweed exposed to the mixture of atrazine with trace metals. Atr $+\mathrm{Cu}, \mathrm{Atr}+\mathrm{Cr}, \mathrm{Atr}+\mathrm{Cu}+\mathrm{Cr}$ : plants exposed simultaneously to atrazine and $\mathrm{Cu}$, atrazine and $\mathrm{Cr}$, atrazine and $\mathrm{Cu}$ and $\mathrm{Cr}$, respectively, at the concentration of $50 \mathrm{\mu gL}^{-1}$ for each experimental chemical. The asterisk indicates the significant difference between control and exposures (* $0.01 \leq p \leq 0.05 ; * * 0.001 \leq p \leq 0.01 ; * \star * p \leq 0.001$ by Kruskal-Wallis test). 

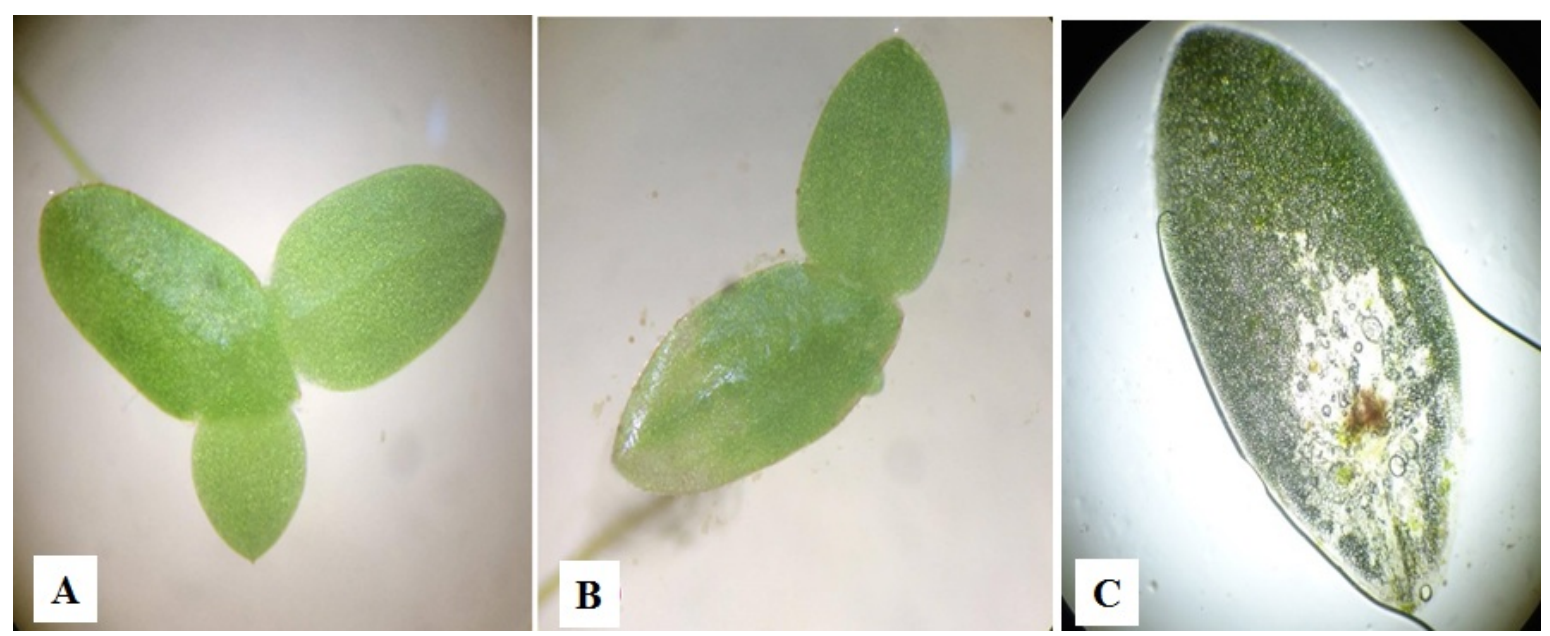

Figure 4. Color of duckweed leaves in control (A), Cu exposure (B) and mixture of Cu and atrazine (C)

\section{Conclusion}

This study revealed that at the low dose $\left(5 \mu g \mathrm{~L}^{-1}\right)$, atrazine could stimulate the growth of duckweed (Lemna minor) whereas when exposed to concentrations (50 and $500 \mu \mathrm{LL}$ $\left.{ }^{1}\right)$, this herbicide resulted in the growth rate being significantly reduced, which eventually caused the death of the plants. Additionally, the synergistic effects on the growth of plants were observed in the combined atrazine and Cu or $\mathrm{Cr}$ exposures, however the mixture of atrazine and $\mathrm{Cu}$ and $\mathrm{Cr}$ caused the antagonistic effects on the growth of plants. Besides, color changes in the leaves of the plants that were exposed to toxins were recorded. These results provided useful information for the quality assessment of water resources when atrazine and metals are present simultaneously, filling thus the knowledge gaps about the ecological toxicity of atrazine-metal complexes. Moreover, further investigations on the interaction mechanisms of herbicides and trace metals also should be carried out. For validation, in situ investigations on the impacts of pesticides and trace metals on plants are suggested.

\section{References}

[1] Ali, N.A., Bernal, M.P., Ater, M. (2002) Tolerance and bioaccumulation of copper in Phragmites australis and Zea mays. Plant Soil, 239: 103-111.

[2] APHA (2012) Standard Methods for the Examination of Water and Waste Water. 22nd Edition, American Public Health Association, American Water Works Association, Water Environment Federation.

[3] Bell, A.M. and Duke, N.C. (2005) Effects of Photosystem II inhibiting herbicides on Mangroves - preliminary toxicology trials. Marine Pollution Bulletin 51(14): 297-307.

[4] Chen, C., Wang, Y., Qian, Y., Zhao, X., Wang, Q. (2015) The synergistic toxicity of the multiple chemical mixtures: Implications for risk assessment in the terrestrial environment. Environment International 77: 95105.
[5] Clijsters, H. and Van Assche, F. (1985) Inhibition of photosynthesis by heavy metals. Photosynth Res 7: 31-40.

[6] Dalton, R. (2002) Frogs put in the gender blender by America's favorite herbicides. Nature 416: 665-666.

[7] Desneux, N., Decourtye, A., Delpuech, J.M. (2007) The sublethal effects of pesticides on beneficial arthropods. Annual Review of Entomology 52: 81-106.

[8] Edivaldo, D.V, Maria L.B.T., Luis, R.M.B, Stephen, O.D. (2010) Growth regulation and other secondary effects of herbicides. Weed Science 58: 351-354.

[9] Forget, G. (1993) Balancing the need for pesticides with the risk to human health. In: Impact of Pesticide Use on Health in Developing Countries. Eds. Forget G, Goodman T and de Villiers A IDRC, Ottawa: 2.

[10] Giardi, M.T., Koblízek, M., Masojídek, J. (2001) Photosystem II-based biosensors for the detection of pollutants. Biosensors and Bioelectronics 16(9-12): 1027 1033.

[11] Graymore, M., Stagnitti, F., Allinson, G. (2001) Impacts of atrazine in aquatic ecosystem. Environment International 26: 483-495.

[12] Hecker, M., Park, J.W., Murphy, M.B., Jones, P.D., Solomon, K.R., Van Der Kraak, G., Carr, J.A., Smith, E.E., du Preez, L., Kendall, R.J., Giesy, J.P. (2005) Effects of atrazine on CYP19 gene expression and aromatase activity in testes and on plasma sex steroid concentrations of male African clawed frogs (Xenopus laevis). Toxicol. Sci. 86: 273-280.

[13] Hughes, J.S., Alexander, M.M., and Balu, K. (1988) An evaluation of appropriate expressions of toxicity in aquatic plant bioassays as demonstrated by the effects of atrazine on algae and duckweed. Amer. Soc. Testing \& Materials. STP 921: 531-547.

[14] Igbedioh, S.O. (1991) Effects of agricultural pesticides on humans, animals and higher plants in developing countries. Arch Environ Health 46(4): 218-224.

[15] Khellaf, N. and Zerdaoui, M. (2009) Growth response 
of the duckweed Lemna minor to heavy metal pollution. Iran. J. Environ. Health. Sci. Eng. 6(3): 161-166.

[16] Kotai, J. (1972) Instructions for preparation on modified nutrient solution Z8 for algae. Norwegian Institute for Water Research, Oslo B-11/69: 1-5.

[17] Lobban, C.S., Chapman, D.J., Kremer, B.P. (1988) Experimental phycology - a laboratory manual. Cambridge University Press, ISBN: 978-0521348348.

[18] Lockert, C.K., Hoagland, K.D., Siegfried, B.D. (2006). Comparative sensitivity of freshwater algae to atrazine. Bulletin of Environmental Contamination and Toxicology 76: 73-79.

[19] McMahon, T.A., Halstead, N.T., Johnson, S., Raffel, T.R., Romansic, J.M., Crumrine, P.W., Boughton, R.K., Martin, L.B., Rohr, J.R. (2011) The fungicide chlorothalonil is nonlinearly associated with corticosterone levels, immunity, and mortality in amphibians. Environ Health Perspect. 119(8):1098-1103.

[20] Meng, Z. and Carper, W.R. (2000) Effects of hydration on the molecular structure of metal ion- atrazine dimer complexes: a MOPAC (PM3) study. J. Mol. Struct. THEOCHEM 531(1-3): 89-98.

[21] Naggar, Y.A., Khalil, M.S., Ghorab, M.A. (2018) Environmental Pollution by Heavy Metals in the Aquatic Ecosystems of Egypt. Open Access Journal of Toxicology, 3(1): 555603.

[22] Ouzounidou, G. (1994a) Copper-induced changes on growth, metal content and photosynthetic functions of Alyssum monatum L. plants. Environ. Exp. Bot. 34: 165-172.

[23] Ouzounidou, G. (1994b) Root growth and pigment composition in relationship to element uptake in Silene compacta plants treated with copper. J. Plant Nutr. 17: 933-943.

[24] Parr, P.D. and Taylor, F.G.J. (1982) Germination and growth effects of hexavalent chromium in Orocol TL (a corrosion inhibitor) on Phaseolus vulgaris. Environ. Int. 7(3): 197-202.

[25] Peralta, J.R., Gardea, T.J.L., Tiemann, K.J., Gomez, E., Arteaga, S., Rascon, E. (2001) Uptake and effects of five heavy metals on seed germination and plant growth in alfalfa (Medicago sativa) L. B. Environ Contam Toxicol 66(6): 727-734.

[26] Phewnil, O.A., Tungkananurak, N., Panichsakpatana, S., Pitiyont, B. (2012) Phytotoxicity of atrazine herbicide to fresh water macrophyte duckweed (Lemna perpusilla Torr.) in Thailand. Environment and Natural Resources Journal 10(1): 16-27.

[27] QCVN 08-MT:2015/BTNMT (2015). National technical regulation on surface water quality. Retrieved from: https://arc.org.vn/quy-chuan-chat-luong-nuoc-matqcvn-08-mt2015btnmt/.

[28] Roberts, S., Vasseur, P., Dive, D. (1990) Combined effects between atrazine, copper, and $\mathrm{pH}$, on target and non-target species. Wat. Res. 24(4): 485-491.

[29] Rohr, J.R., Elskus, A.A., Shepherd, B.S., Crowley, P.H., McCarthy, T.M., Niedzwiecki, J.H., Sager, T., Sih, A., Palmer, B.D. (2003) Lethal and sublethal effects of atrazine, carbaryl, endosulfan, and octylphenol on the streamside salamander (Ambystoma barbouri). Environ. Toxicol. Chem. 22(10): 2385-2392.

[30] Rohr, J.R. and McCoy, K.A. (2010) A qualitative metaanalysis reveals consistent effects of atrazine on freshwater fish and amphibians. Environmental Health Perspectives 118(1): 20-32.

[31] Rout, G.R., Sanghamitra, S., Das, P. (2000) Effects of chromium and nickel on germination and growth in tolerant and non-tolerant populations of Echinochloa colona (L). Chemosphere 40(8): 855-859.

[32] Sheldon, A., Menzies, N.W. (2005) The effect of copper toxicity on the growth and root morphology of Rhodes grass (Chloris gayana) in resin buffered solution culture. Plant and Soil 278(1-2): 341-349.

[33] Stark, J.D. and Banks, J.E. (2003) Population-level effects of pesticides and other toxicants on arthropods. Annual Review of Entomology 48: 505-519.

[34] Wang, W. (1990) Literature review on Duckweed toxicity testing. Environmental Research 52(1): 7-22.

[35] Wang, J.H., Zhu, L.S., Meng, Y., Wang, J., Xie, H., Zhang, Q.M. (2012) The combined stress effects of atrazine and cadmium on the earthworm Eisenia fetida. Environ. Toxicol. Chem. 31(9): 2035-2040.

[36] WHO. World Health Organization. Switzerland: Geneva; 1996. Trace Elements in Human Nutrition and Health.

[37] Yang, G., Chen, C., Wang, Y., Cai, L., Kong, X., Qian, Y., Wang, Q. (2015) Joint toxicity of chlorpyrifos, atrazine, and cadmium at lethal concentration to earthworm Eisenia fetida. Environ. Sci. Pollut. Res. Int. 22(12): 9307-9315. 